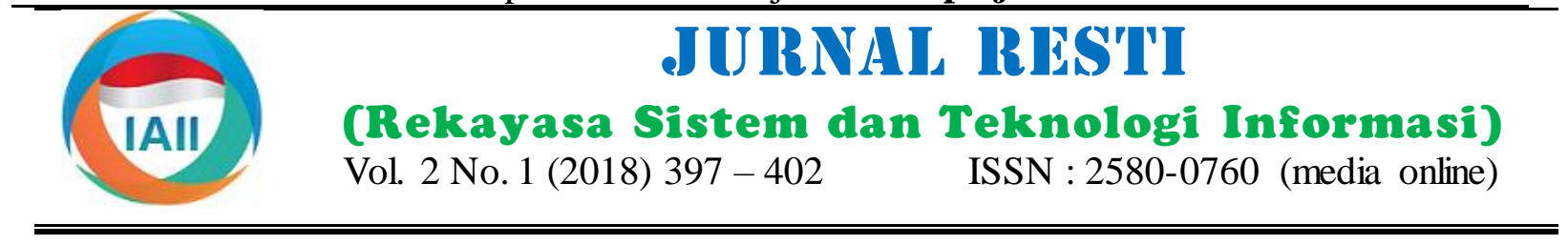

\title{
Autonomous Sales Robot untuk Pengenal Produk Berbasis Barcode dan Arduino ATMega328
}

\author{
Ikhsan ${ }^{\mathrm{a}}$, Ade Afdhika Putra ${ }^{\mathrm{b}}$ \\ ${ }^{a}$ Manajemen Informatika, AMIK Jayanusa Padang, riksjp21@gmail.com \\ ${ }^{\mathrm{b}}$ Sistem Komputer, STMIK Jayanusa Padang, aafdhika11@ @mail.com
}

\begin{abstract}
This paper discusses similar machines of people who are categorized as robots that function as product identifier sales. This research is used as a substitute for shop assistants who sometimes have an emotional attitude when the consumer asks many things. By utilizing this robot, is expected to provide more services to consumers, consumers only need to show the goods that will be desired to the robot by closing the barcode, and the robot will provide information to the product in detail. In the process of this research is made by waterfall method with the necessary changes. From the results of the study concluded that the robot system can provide information services to consumers.
\end{abstract}

Keywords: Robot, Sales, Barcode, Arduino, Atmega328

\begin{abstract}
Abstrak
Paper ini membahas mesin serupa orang yang dikategorikan sebagai robot yang berfungsi sebagai sales pengenal produk. Penelitian ini dimanfaatkan sebagai pengganti pelay an toko yang kadang memiliki sikap emosional saat konsumen bertanya banyak hal. Dengan memanfaatkan robot ini, diharapkan dapat memberikan pelay anan lebih terhadap komsumen, konsumen hany a perlu memperlihatkan barang y ang akan diinginkan kepada robot dengan mendekatkan bagian barcode, dan robot akan memberikan informasi kepada produk tersebut secara rinci. Dalam proses penelitian ini dibuat dengan menyadur metode waterfall dengan pengubahan seperlunya. Dari hasil penelitian di dapatkan kesimpulan bahwasany a sistem berupa robot dapat memberikan informasi pelay anan kepada konsumen.
\end{abstract}

Kata kunci: Robot, sales, Barcode, Arduino, Atmega328

(C) 2018 Jurnal RESTI

\section{Pendahuluan}

Perubahan teknologiberkembang begitu pesat, sehingga

dibutuhkan pemikiran-pemikiran yang inovatif dengan Khusus dalam memperkenalkan produk, perusahaan menggunakan peralatan seminimal mungkin untuk hanya mengunakan tenaga manusia yang disebut juga sebuah aplikasi tertentu yang bermanfaat untuk dengan sales, dimana sales yang disediakan oleh kehidupan di masyarakat. Hal yang sama dengan perusahaan saat ini masih terbatas, dan terkadang sales perkembangan dibidang teknologi khususnya dibidang tidak memberikan informasi yang lengkap kepada elektronika dan robotika, menuntut automatisasi dalam konsumen, sehingga perbandingan sales dengan segala hal yang dapat meringankan pekerjaan manusia konsumen tidak sesuai dengan yang diharapkan dan dan menjadikan segalanya mudah dipakai dan dapat mengakibatkan konsumen tidak mendapatkan informasi mendatangkan keuntungan.

yang lengkap tentang produk yang diinginkan.

Pembuatan robot-robot dengan keistimewaan khusus ini Untuk membantu kinerja sales dalam memperkenalkan sangat berkaitan erat dengan adanya kebutuhan dalam dan mempromosikan suatu produk tersebut perlu adanya dunia industri modern, maka dikembangkan pula suatu suatu mesin (robot)yang berbentukhumanoid yang bisa tekknologi yang mampu mengadopsi cara berfikir mengenal suatu produk dan memberikan informasi manusia yaitu teknologi Artificial Intelegence atau tentang produk tersebut ke konsumen, sehingga kecerdasan buatan, yang menuntut adanya suatu alat konsumen tidak perlu lagi mencari sales untuk dengan kemampuan yang tinggi yang dapat membantu mengetahui informasi produk tersebut, cukup menyelesaikan pekerjaan manusia ataupun untuk mengambil suatu produk yang konsumen inginkan dan dekatkan produk tersebut ke robot maka robot akan Diterima Redaksi : 28-02-2018 $\mid$ Selesai Revisi : 18-04-2018 $\mid$ Diterbitkan Online : 19-04-2018 
membaca barcode dari suatu produk itu dan menjelaskan spesifikasi dari produk tersebut ke konsumen.

Penelitian ini melihat aspek yang harus dipecahkan masalahnya dalam latar belakang masalah di atas, sehingga dapat menjadi rujukan apa saja yang harus dilakukan sistem yang akan dibangun, semisal untuk menjawab pertanyaan-pertanyaan berikut : bisakah robot dapat mendeteksi produk dengan mendekatkan produk tersebut ke robot? Mampukah robot berinteraksi dengan konsumen dengan memanfaakan fitur suara dari si robot? Dan dapatkan Arduino atmega328 melakukan semua proses sehingga board mikrokontroller ini dapat menjadi pengendali robot agar bekerja sebagaimana mestinya?

\section{Tinjauan Pustaka}

\subsection{Autonomous Robot}

Banyak penelitian yang mengambil tema robotik (Universal Price Code) atau pembaca harga barang robotik sudah menjadi bagian manufaktur yang maju secara otomatis, namun juga dipakai pada kartu identitas lebih dari setangah abad. Robot dan peralatan peripheral dan surat pos untuk identifikasi jumlah produk tertentu sudah menjadi sangat canggih, handal, dan dalambentuk [8]. Barcode secara umum memiliki 2 jenis simbol yakni miniatur. Sistem ini banyak dimanfaatkan dalam bidang barcode lenear (1D), dan barcode Matrix (2D) yang hiburan, militer, dan pengawasan. [1]

Menurut [2], Robotika adalah bidang ilmu yang campur aduk, seperti : transformasi geometris, teori control, sistem operasi real time, Motor DC dan stepper, dan Pemrosesan digital.

Paling utama dalam robotik adalah sistem kontrol, dimana sistem kontrol mencakupi proses umpan balik bekerja sama dengan mesin fisik [3]. Biasanya design sistem kontrol ini dimaksudkan pada kondisi loop terbuka dan loop tertutup.

Robot Autonomous menangani satu fungsi khusus, dimana didalam penelitian ini bertugas untuk melayani pelanggan.

\subsection{Catu Daya}

Sebagai Penyuplai tegangan dibutuhkan rangkaian catu daya yang stabil, rangkaian catu daya yang dibutuhkan adalah sebagai sumber tenaga robot agar robot dapat beroperasi dengan baik. Catu daya merupakan rangkaian filter penyearah, sehingga rangkaian tersebut akan merubah tegangan AC menjadi DC. Menurut [4] rangkaian yang sederhana dapat menggunakan komponen dasar elektronika seperti transformator, penyearah (dioda), resistor, kapasitor, dan induktor.

\subsection{Arduino Atmega328}

Hampir tujuh ratus ribu jenis Arduino beredar dipasaran, dari jumlah tersebut, mikrokontroller Arduino Atmega328 terdiri dari 14 input dan output pin analog dan digital (dari 6 pin yang dianggap sebagaipin PWM), 6 input analog dan digitalyang tersisa. Kabel soket daya digunakan untuk menghubungkan papan arduno dengan komputer. [5]
Mikrokontroller Atmega328 memiliki fitur dengan kinerja yang tinggi, mikrokontroller AVR-8 bit berdaya rendah, bekerja pada suhu $-40^{\circ} \mathrm{C}$ sampai $85^{\circ} \mathrm{C}$, kecepatan berada pada kisaran $0-20 \mathrm{MHz}$, memiliki 6 saluran PWM dan memiliki counter real time dengan osilator terpisah. Menggunakan arsitektur RISC dengan operasi statis juga memiliki kunci kemanana pemrograman. [6]

\subsection{Sensor Barcode}

Sensor merupakan pondasi bangunan yang penting untuk revolusi industri yang maju saat sekarang [7], sensor merubah cara pandang manusia dalam menangani masalah, karena sensor sama halnya alat indra yang ada pada manusia. Dengan sensor inilah alatalat industri dan robotika dapat memahami kondisi lungkungan sekitar.

Secara umum barcode digunakan sebagai UPC banyak digunakan, namun ada juga barcode 3D yang sudah ada dan sedang dikembangkan. [9]. Gambar barcode 1D dan 2D dapat dilihat pada Gambar 1.

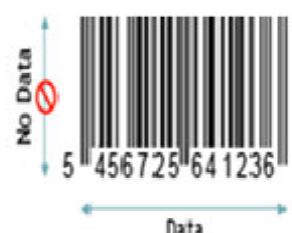

Data

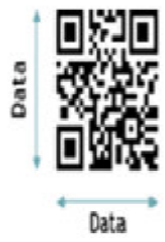

Gambar 1. Barcode 1D dan 2D[10]
Dengan menggunakan barcode inilah, robot akan mendeteksinya serupa jadi sensor, dimana sensor akan membaca kode barcodenya dan Arduino Atmega328 yang akan memproses.

\subsection{Pelayan Toko (Sales)}

Peran sales pada pertokoan dimanfaatkan untuk melayani konsumen dan bertanggung jawab pada penjualan. Banyak kondisi terjadi jika penjualan menurun yang disalahkan adalah sales. Jadi disini akan terlihat sekali peran sales sunguh sangat penting. Proses niaga yang dilakukan perorangan maupun perusahaan tak lain adalah untuk memproleh laba yang optimal untuk keberlangsungan hidup perusahaan. [11]

\section{Metodologi Penelitian}

Proses penyelesaian masalah dalam penelitian ini menyadur metode waterfall yang dirubah sedemikian rupa. Metode waterfall sendiri memiliki tahapantahapan seperti : planning, analysis, design, implementation, testing dan maintenance. [12] 


\subsection{Planning}

Penelitian diawali dengan perncanaan pendahuluan dan pengumpulan data. Penelitian pendahuluan merupakan tahapan yang penting dalam penelitian, dengan penelitian pendahuluan inilah kita bisa menggali informasi-informasi awal yang akan menguatkan asumsi-asumsi[13]. Pengumpulan data dilakukan dengan model pengamatan langsung di beberapa toko dan mencari referensi-referensi yang menguatkan isi asumsi.

\subsection{Analysis}

Berdasarkan masalah yang sudah di identifikasi, dibutuhkan proses analis is data. Hal ini bertujuan untuk menemukan solusi terbaik dari pemecahan masalah.

\subsection{Design}

Perancangan yang dilakukan adalah dengan memanfaatkan blog diagram, contex diagram, dan data flow diagram. Sehingga dengan diagram-diagram tersebut akan mempermudah tahapan implementasi dan pengujian

\subsection{Implementation}

Setelah dibantu dengan diagram-diagram sebelumnya, tahapan ini bisa dijalankan. Sehingga proses pemasangan perangkat antar blog dan memprogram sistem dapat berjalan dengan baik.

\subsection{Testing}

Ini tahapan terakhir, semua akan di tes baik kinerja masing-masing komponen maupun sistem secara keseluruhan. Apakah sudah berjalan dengan baik atau masih ada bug.

\subsection{Maintanance}

Jika sudah tidak ada kendala, tahapan ini bis a dijalankan dengan mencek apakah perlu ada pengembangan sistem dengan tingkat lanjut, pemeliharaan dan lain sebagainya yang sekiranya perlu dilakukan.

\section{Hasil dan Pembahasan}

Dari hasil analisis diharapkan sistem ini dapat membantu atau bahkan bisa menggantikan pelayanan pada toko. Dalam sistem robot ini melibatkan unit masukkan (input) yang kemudian di proses sehingga menghasilkan dalam bentuk keluaran (output). Garis besar analis is sistem terlihat pada Gambar 2 .

Dari analisis di atas dapat dirincikan dalam bentuk blog diagram, lihat Gambar 3. suplay (Catu Daya). Power button di manfaatkan untuk memutus dan menyambungkan sistem dengan sumber tegangan. Untuk pembacaan barcode dibutuhkan sensor barcode yang berperan sebagai input. Proses akan dilakukan oleh Arduino Atmega328, serta ouput berupa suara yang di eksekusi oleh Modul Mp3 dan gerakan tangan yang dijalankan oleh motor servo.

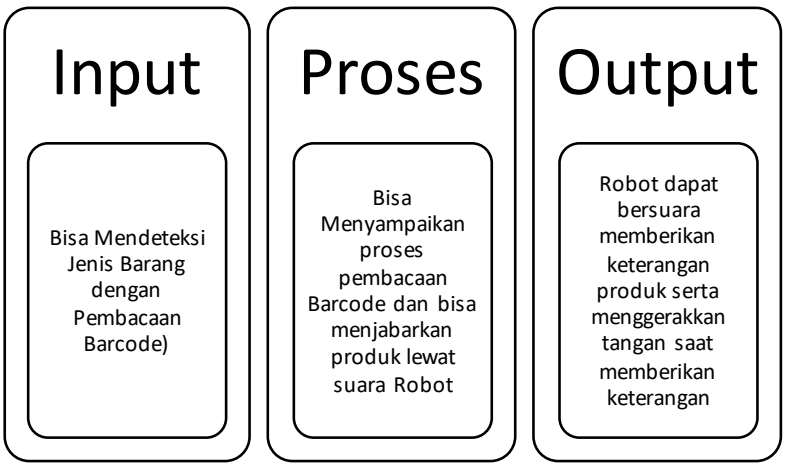

Gambar 2. Garis Besar Analisis Sistem

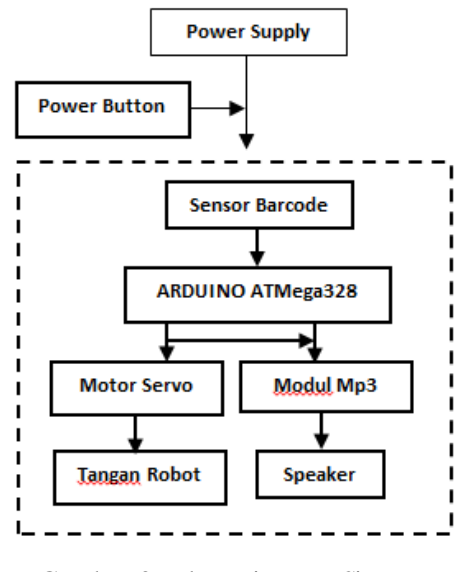

Gambar 3. Blog Diagram Sistem

Penjabaran setiap external entity secara keseluruhan dalam sistem ini dapat diGambarkan melalui context diagram. Context diagram merupakan pendefinisian terhadap sistem yang akan dirancang yang bersifat menyeluruh. Context diagram ini digunakan untuk memudahkan dalam proses penganalisis an sistem yang dirancang secara keseluruhan. Context diagram berfungsi sebagai media, yang terdiri dari suatu proses dan beberapa external entity. Contex diagram yang dimaksud dapat dilihat pada Gambar 4.

Dari contex diagram diatas dapat didambarkan aliran data seperti tampak pada Gambar data flow diagram pada Gambar 5.

Dari perancangan di atas mempermudah dalam menyusun atar sub bagian dari rangkaian secara fisik rangkaian keseluruhan dari masing-masing sub bagian seperti pada Gambar 6.

Dari hasil analisis, perancangan blog diagram dapat Rangkaian tersebut disusun dan diatur sedemikian rupa mewakili masing-masing subblog. Sebagai pensupport dalam kerangka robot. Serta merta masing-masingnya tegangan dalam sistemmaka dibutuhan rangkaian power seperti design robot pada Gambar 7. 


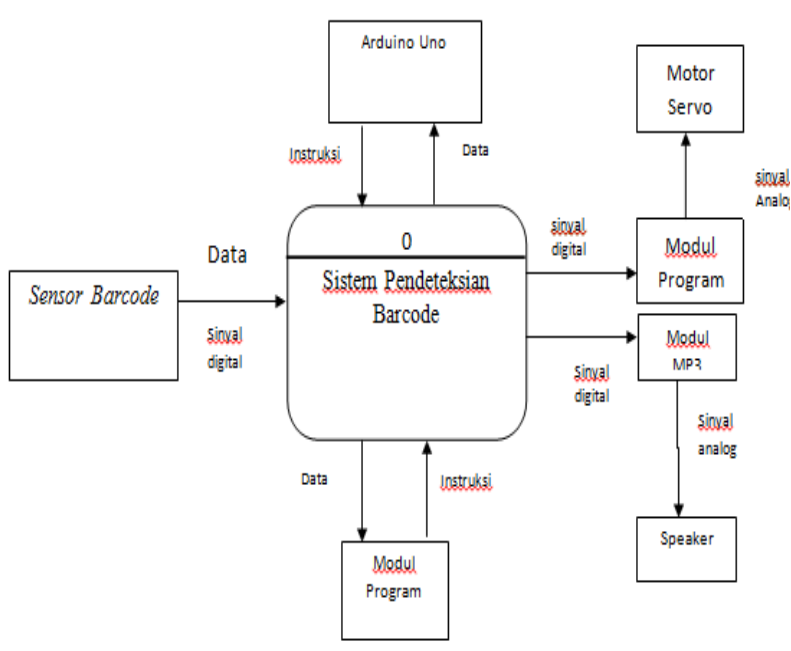

Gambar 4. Contex Diagram Sistem

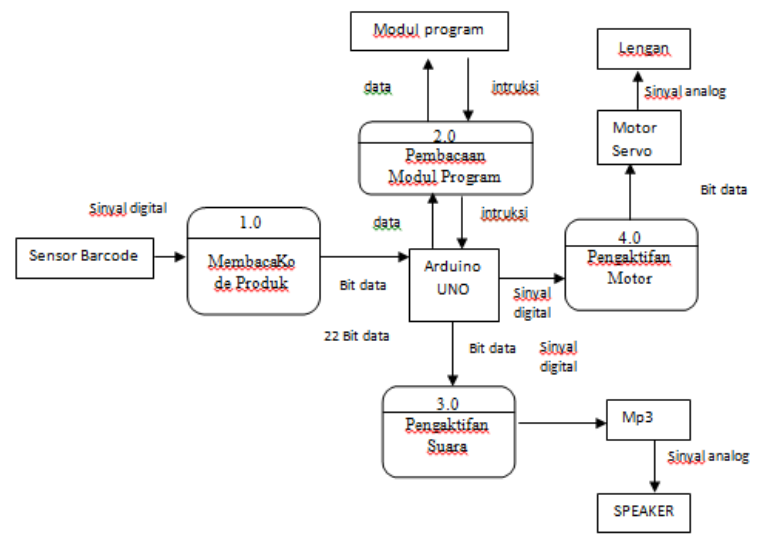

Gambar 5. Data Flow Diagram Sistem

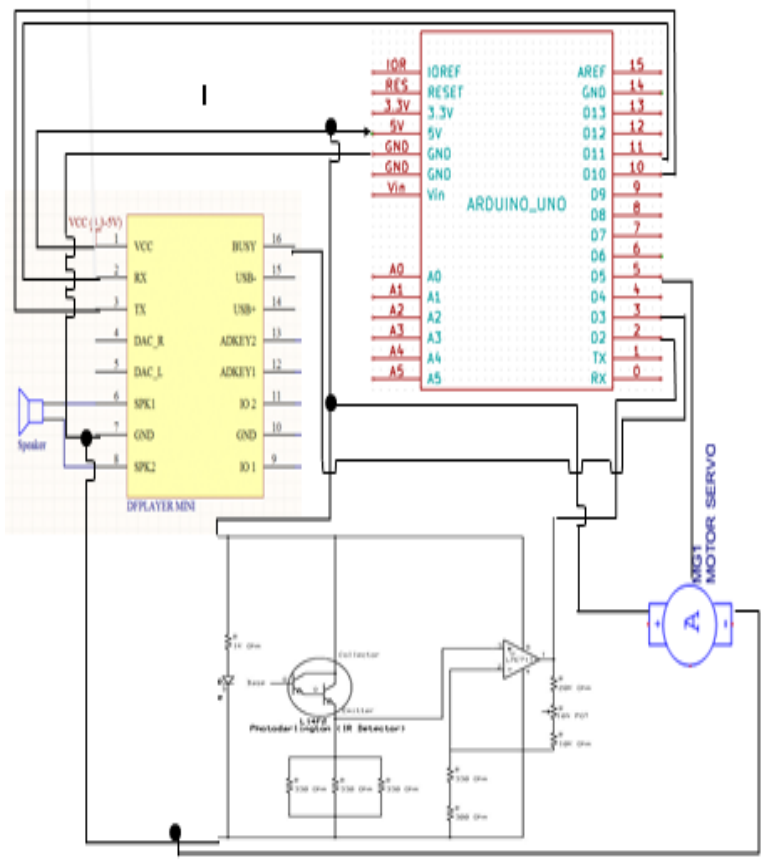

Gambar 6. Rangkaian Keseluruhan Sistem

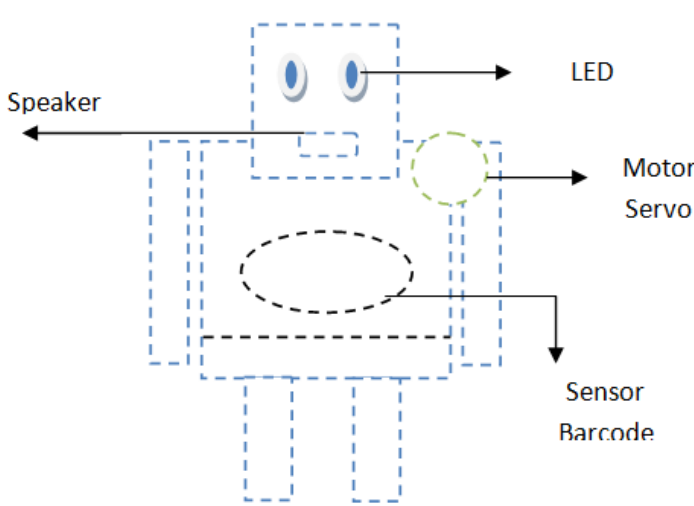

Gambar 7. Kerangka Robot dan tata letak komponen

Modul program dirancang memiliki struktur dengan kualitas yang baik dan mudah dimengerti, maka sebelum pembuatan listing program perlu diawali dengan penentuan logika program. Logika das ar gambaran pada penulisan ini adalah dengan menggunakan flowchart seperti Gambar 8.

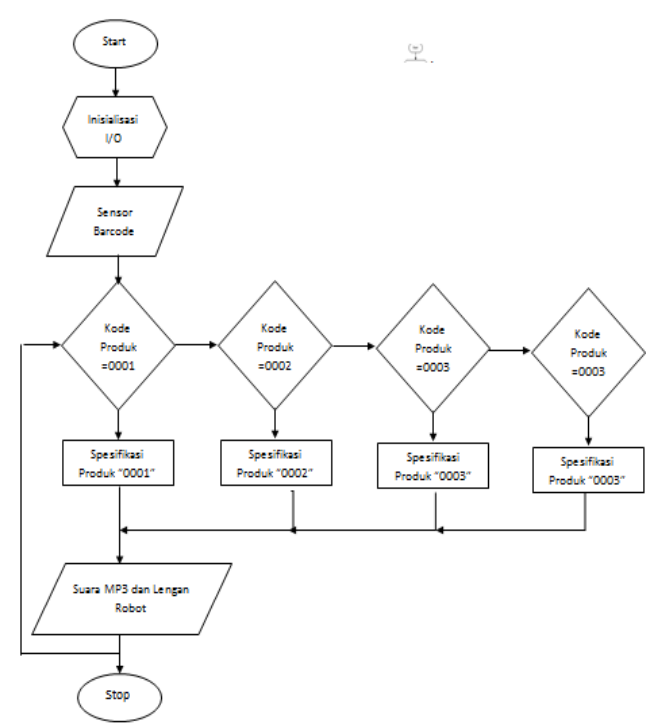

Gambar 8. Flowchart Robot

Pengujian dilakukan untuk melihat hasil seperti Gambar 9.

Dari Gambar 9 dapat terlihat saat tombol robot diaktifkan, robot akan aktif dan mengeluarkan suara yang sudah terekam.

"Hello apa kabar, saya adalah alat pengenal produk menggunakan barcode, silahkan dekatkan barcode produk yang ingin anda ketahui spesifikasinya." 


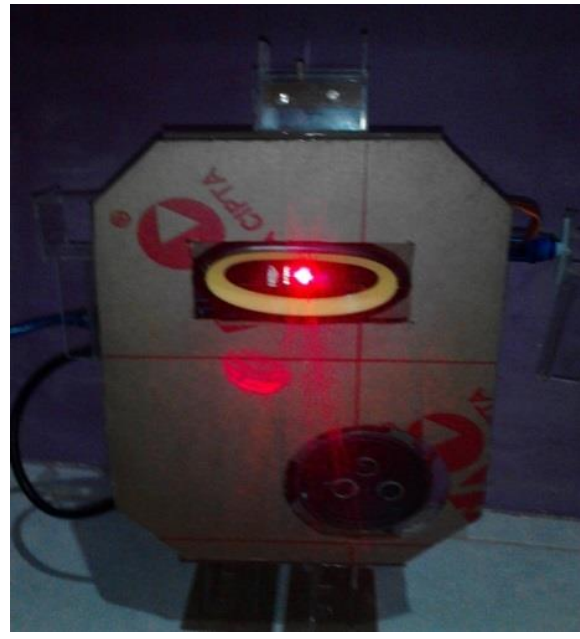

Gambar 9. Robot Aktif

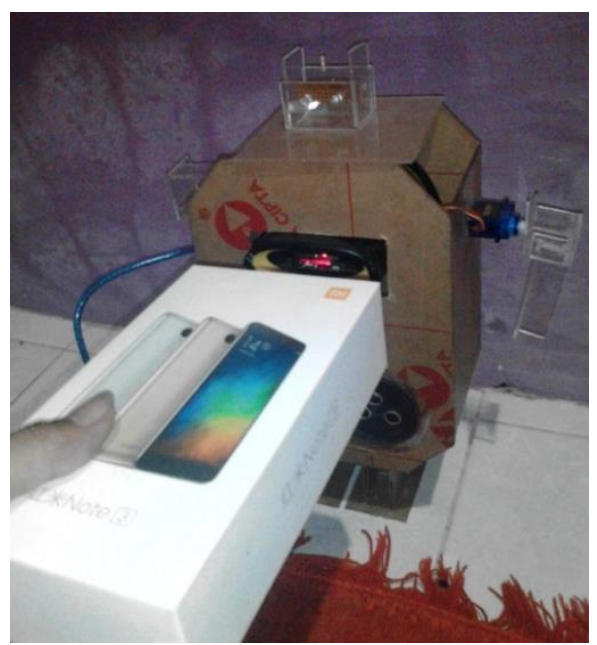

Gambar 10. Robot membaca Product

Saat didekatkan sebuah produk seperti pada Gambar di atas, robot akan menjelaskan spesifikasi lengkap dari produk tersebut.

"Xiaomi Redmi Note 3 yang memiliki Bodi $150 \times 76 \times$ 8,7 mm, dengan berat164 gram, yang memiliki Prosesor MediaTek Helio X10 octa-core $2.0 \mathrm{GHz}, \mathrm{RAM} 3 \mathrm{~GB}$ dengan penyimpanan internal $32 \mathrm{~GB}$, ukuran layar 5,5 inchi, memiliki kamera depan 5 MP dan kamera belakang 13 MP, dengan kapasitas baterai $4.000 \mathrm{mAh}$, dan sudah dilengkapi dengan Sensor Fingerprint, accelerometer, gyro, proximity, compass. Jika anda berminat silahkan menuju ke kasir yang telah disediakan. TERIMA KASIH"

Setelah dilakukan pengujian, berikut didapat hasil perbandingan antara Human Sales dengan Robot Sales. [3 Hasil perbandingan dapat dilihat dalam Tabel 1.
Tabel 1.Human Sales VS Robot Sales

\begin{tabular}{|c|c|c|}
\hline Pengujian & $\begin{array}{l}\text { Human } \\
\text { Sales }\end{array}$ & Robot Sales \\
\hline $\begin{array}{l}\text { Pengetahuan } \\
\text { tentang Produk }\end{array}$ & $\begin{array}{l}\text { Tidak } \\
\text { mengetahui } \\
\text { semua } \\
\text { (lupa) dan } \\
\text { tidak rinci }\end{array}$ & $\begin{array}{l}\text { Mengetahui } \\
\text { semua dengan } \\
\text { sangat Rinci }\end{array}$ \\
\hline $\begin{array}{l}\text { Pengaruh } \\
\text { Mood }\end{array}$ & $\begin{array}{l}\text { Ada yang } \\
\text { terpengaruh } \\
\text { pada mood, } \\
\text { ada yang } \\
\text { tidak }\end{array}$ & $\begin{array}{l}\text { Tidak } \\
\text { berpengaruh } \\
\text { pada mood sama } \\
\text { sekali }\end{array}$ \\
\hline Bahasa Tubuh & $\begin{array}{l}\text { Dinamis } \\
\text { pada semua } \\
\text { anggota } \\
\text { tubuh }\end{array}$ & $\begin{array}{l}\text { Statis, hanya } \\
\text { pada lengan saja }\end{array}$ \\
\hline $\begin{array}{l}\text { Ketersediaan } \\
\text { waktu }\end{array}$ & Terbatas & Alwas \\
\hline Bahasa & Fleksibel & Kaku \\
\hline
\end{tabular}

\section{Kesimpulan}

Dari penelitian yang sudah dilakukan,dapat ditarik kesimpulan dan saran sebagai berikut.

\subsection{Simpulan}

1. Robot dapat berperan sebagai sales dalam memperkenalkan dan mempromosikan produk dengan cara mendekatkan produk tersebut ke robot

2. Robot dapat menggantkan peran human sales, namun ada beberapa hal yang tidak bisa tergantikan, misal dalam hal Bahasa yang jauh lebih fleksibel atau gerak tubuh yang lebih dinamis

\subsection{Saran}

1. Keterbatasan media penyimpanan memori pada mikrokontroller berimbas pada ruang penyimpanan pengenalan produk, alangkah lebih bagus jika disediakan database yang bisa terkoneksi dengan cloud.

2. Lebih mendinamiskan lagi perilaku robot seperti gerak tubuh yang tidak kaku, atau penambahan kosa kata Bahasa sehingga bahasanya lebih fleksibel.

\section{Daftar Rujukan}

[1] W. Budiharto, "Intelligent Surveillance Robot with Obstacle Avoidance Capabilities Using Neural Network," Comput.Intell. Neurosci., vol. 2015, 2015.

[2] P. . Ramaiah, M. Venkateswara Rao, and G. V Satyanarayana, "A Microcontroller Based Four Fingered Robotic Hand,"Int.J. Artif. Intell. Appl., vol. 2, no. 2, pp. 90-102, 2011.

[3] S. C. Jacobsen et al., "Research robots for applications in artificial intelligence, teleoperation and entertainment," Int.J. Rob. Res., vol. 23, no. 4-5, pp. 319-330, 2004.

[4] S. Kaputama and J. V. No, "Perancangan Robot PembacaCaris Hitam Berbasis Mikrokontroler," vol. 7, no. 2,pp.28-37,2014.

[5] R. H. Sudhan, M. G. Kumar, A. U. Prakash, S. A. R. Devi, and S. P., "Arduino Atmega-328 Microcontroller," Ijireeice, vol.3, 
no. 4, pp. 27-29, 2015

[6] R. H. M. Ganesh, K. A. Udhaya, and P. P. Sathya, "Stepper Motor Control using ARDUINO ATMEGA - 328 MicroController saranathan College of Engineering," Int. J. Sci. Res. Dev., vol. 2, no. 12, pp. 778-780, 2015.

[7] M. Hammoudeh and M. Arioua, "Sensors and Actuators in Smart Cities," J. Sens. Actuator Networks, vol. 7, no. 1, p. 8, 2018.

[8] F. Wahyutama, F. Samopa, and H. Suryotrisongko, "Penggunaan T eknologi Augmented Reality Berbasis Barcode sebagai Sarana Penyampaian Informasi Spesifikasi dan Harga Barang yang Interaktif Berbasis Android, Studi Kasus pada Toko Elektronik ABC Surabaya," J. Tek. ITS, vol. 2, no.3,pp. A481-A486, 2013

[9] J. Phaniteja and P. D. J. Tom, "Evolution of barcode," Int. J. Develompment Comput. Sci. Technol., vol. 7884, 2010.
[10] R. Article and B. Sciences, "Classification of Dna Barcodes Based on Image Processing Techniques: a Study," Int. J. Pharma Bio Sci., vol. 7, no. 3, pp. 773-780, 2016.

[11]W. A. L. Didik Darmadi, Suharyono, "PENGARUH PROMOS PENJUALAN TERHADAP PENJUALAN (Studi Kasus PT . Astra Internasional T bk-T SO Cabang Soetoyo Malang),"J.Adm. Bisnis, vol. 2, no. 1, pp. 21-28, 2013.

[12]Y. Suherman, "Sistem Informasi Kearsipan Tata Kelola Surat Pada Kantor Inspeksi Kota Padang,” J. Resti, vol. 1, no.1,pp.9$18,2017$.

13]R. A. Mahessya, L. Mardianti, and R. Sovia, "Pelanggan Menggunakan Metode Monte Carlo Pada Pt Pos Indonesia ( Persero ) Padang," J. Ilmu Komput., vol. 6, no.1,pp.15-24,2017. 